\title{
Acute cardiac complications and subclinical myocardial injuries associated with pheochromocytoma and paraganglioma
}

\author{
Jing Zhou ${ }^{1 \dagger}, \mathrm{He}_{\mathrm{Xuan}}{ }^{\dagger}$, Yunxiang Miao ${ }^{2}$, Junting $\mathrm{Hu}^{1}$ and Yunlang Dai ${ }^{1 *}$
}

\begin{abstract}
Background: Catecholamine excess arising from pheochromocytomas and paragangliomas (PPGLs) can cause a wide spectrum of cardiac manifestations, including acute cardiac complications (ACCs) and subclinical myocardial injuries (SMIs). In this study, we aimed to conduct a comprehensive analysis of ACCs and SMIs in a large cohort of patients with PPGLS.
\end{abstract}

Methods: We retrospectively analyzed the clinical data of consecutive patients with PPGLs admitted between January 2013 and July $2020(n=189)$. The prevalence of ACCs and SMls and characteristics of patients identified with ACCs and SMIs were investigated. Moreover, comparisons were performed between patients with and without ACCs.

Results: Fourteen patients (7.4\%) fulfilled the criteria for ACCs, including nine (4.8\%) who presented with Takotsubolike cardiomyopathy, four (2.1\%) with heart failure with preserved ejection fraction, and finally one (0.5\%) with catecholamine-induced cardiomyopathy. Compared to those without ACCs $(n=175)$, patients with ACCs had a higher prevalence of epinephrine-producing PPGLs (81.8\% vs 33.9\%, $P=0.006)$ and were more likely to show invasive behavior ( $61.5 \%$ vs $27.3 \%, P=0.022)$ or hemorrhage/necrosis ( $53.9 \%$ vs $17.4 \%, P=0.005)$ on histology. The apical sparing pattern $(5 / 7,71.4 \%)$ was the dominant impairment pattern of longitudinal strain (LS) for patients displaying Takotsubo-like cardiomyopathy. In patients without cardiac symptoms, a fairly high proportion (21/77, 27.3\%) of patients who underwent screening for troponin and/or natriuretic peptide and/or echocardiography had SMls.

Conclusions: One in every fourteen PPGL patients presented with ACCs, and in the patients with Takotsubo-like cardiomyopathy, the apical sparing pattern was the primary impairment pattern of LS. Additionally, nearly one-third of patients without symptoms had SMls. The diagnosis of PPGLs should be considered in patients with acute reversible cardiomyopathy, especially in those exhibiting an apical sparing pattern of LS.

Keywords: Pheochromocytoma, Cardiac complication, Myocardial injury, Longitudinal strain

\section{Background}

Pheochromocytomas (PHEOs) and paragangliomas (PGLs) (PPGLs), secreting catecholamines (CAs), are rare tumors and have a wide variety of cardiovascular

*Correspondence: daiyunlang@suda.edu.cn

${ }^{\dagger}$ Jing Zhou and He Xuan have contributed equally to this work

1 Department of Cardiology, The First Affiliated Hospital of Soochow

University, 188 Shizi Road, Suzhou City 215006, People's Republic of China

Full list of author information is available at the end of the article manifestations and complications, which were reviewed recently [1]. Clinically, the presentations of PPGLs are usually nonspecific, and only a limited proportion of patients display the classic triad of headache, palpitation and sweating, resulting in delays in diagnosis, especially in patients presenting with cardiac symptoms $[2$, 3]. Acute cardiac complications (ACCs) due to an excess amount of CAs, including epinephrine, norepinephrine, and sometimes dopamine, in patients with PPGLs may 
be life-threatening; hence, timely diagnosis and surgery can be life-saving [1]. To date, a few retrospective series of PPGLs have been reported from cardiac perspectives, revealing that the prevalence of ACCs varies from $11 \%$ to $19.3 \%[4-8]$.

ACCs related to PPGLs encompass arrhythmias (bradycardia and tachycardia), Takotsubo-like cardiomyopathy, dilated cardiomyopathy, thromboembolism, acute coronary syndrome, and so on [1]. PPGLs are considered secondary causes of Takotsubo syndrome (TTS) in the European Society of Cardiology (ESC) expert consensus, and dozens of cases have been reported so far [3, 9].

In the current study, we retrospectively reviewed patients diagnosed with PPGLs in our center and screened carefully for patients with ACCs. The prevalence and features of PPGLs and outcomes of PPGL patients with ACCs were assessed; furthermore, comparisons between patients with and without ACCs were conducted to identify the patient features associated with ACCs. Additionally, subclinical myocardial injuries (SMIs) were also investigated to reveal CA-induced cardiac damage that did not cause clinical symptoms.

\section{Methods}

\section{Study populations}

Consecutive patients diagnosed with PPGLs (clinical or histopathological diagnoses) and admitted between January 2013 and July 2020 were included for analysis. Clinical diagnoses were established by classic CArelated paroxysmal complaints (headache, palpitations, and/or profuse sweating) in combination with adrenal tumors with features suggestive of PPGLs on computed tomography $(\mathrm{CT})$ or magnetic resonance imaging (MRI) and elevated plasma CA or metanephrine (MN)/normetanephrine (NMN) levels at least two times the upper limit of normal (ULN) [10]. In total, 189 patients identified with PPGLs were included in the analysis, of whom 185 had their diagnoses confirmed by histopathology.

Meanwhile, we searched electronic medical records for patients diagnosed with acute coronary syndrome (ACS) and/or acute heart failure (AHF), aiming to draw a picture of the prevalence of PPGLs in these patients.

\section{Clinical assessments}

Data on demographic factors, patterns of hypertension, clinical presentations, electrocardiogram (ECG) alterations, biochemical examinations, preoperative plasma $\mathrm{CA}$ and MN/NMN levels, echocardiography results, characteristics of tumors, and in-hospital outcomes were recorded. The patterns of hypertension included normal, sustained (just as essential hypertension), paroxysmal (paroxysms of hypertension on a background of normal blood pressure), mixed (paroxysms of hypertension on a background of sustained hypertension) and unknown patterns [2]. Hypertension was based on the diagnosis at admission and preoperative blood pressure readings, as blood pressure might decline after surgery. Two classification approaches were used for the patterns of secretion: (1) nonsecreting, epinephrine predominant $(\geq 2 \times \mathrm{ULN}$, including $M N)$, norepinephrine predominant $(\geq 2 \times U L N$, including NMN), and a combination of both; and (2) with and without epinephrine secretion $(\geq 2 \times U L N$, including MN) [4]. Maximal tumor diameters were comprehensively determined by gross pathological specimens and preoperative CT/MRI. The estimated glomerular filtration rate (eGFR) was calculated using the CKD-EPI method [11].

The diagnoses of ACCs were established in the presence of at least one of the following clinical situations before surgery: (1) Takotsubo-like cardiomyopathy diagnosed by the following combination [9]: (I) transient left ventricular dysfunction with wall-motion abnormality extending beyond a single epicardial coronary artery distribution; (II) either absence of significant coronary artery stenosis confirmed by coronary artery angiography (CAG) or coronary computed tomography angiography (CTA), or no risk factors; (III) ECG abnormalities or elevated cardiac biomarkers; and IV) no evidence of viral infection; (2) heart failure with unknown aetiologies, most likely attributed to CA release from PPGLs, requiring hospitalizations or intravenous diuretic therapy; and (3) systemic thromboembolism of presumed cardiac origin, arrhythmias requiring hospitalizations or antiarrhythmic therapy, and any other cardiac event that was believed to be related to PPGLs.

In addition, SMIs were assessed to reveal detectable myocardial insults before surgery in patients without cardiac symptoms. An SMI was defined as any identified abnormality in myocardial injury biomarkers (highsensitivity cardiac troponin $\mathrm{T}$ ) or $\mathrm{N}$-terminal pro-B type natriuretic peptide (NT-proBNP) levels or systolic ventricular dysfunction identified using two-dimensional (2D) strain analysis in the absence of overloading or other conditions that could alternatively explain the abnormal findings.

In suitable patients, 2D strain analysis was performed offline by a single experienced examiner (Y.X. Miao) using dedicated software (EchoPAC, Norway). Data on parameters including global longitudinal strain (GLS), impairment patterns of longitudinal strain (LS) (e.g., apical; apical sparing which was defined as segments in midventricular and basal regions with reduced LS, whereas the segment in the apical region had relatively normal LS; segmental; and global) and any other valuable information were documented. 
All patient records were anonymized before analysis and the Institutional Review Board (IRB) waived the requirement for informed consent due to the retrospective nature of the study. The study protocol was approved by the IRB of Soochow University and followed the principles of the Helsinki Declaration.

\section{Statistical analysis}

Continuous variables were assessed for normality by the skewness/kurtosis test and expressed as the mean \pm standard deviation (SD) or median (25th, 75th percentile), as appropriate. Means were compared using a 2-tailed Student's t-test or, in the case of non-normal data, the rank sum test. Categorical variables were shown as numbers (percentages), and differences were detected using the Pearson chi-square test or Fisher's exact test, where appropriate. All analyses were carried out using STATA version 14.0 (Stata Corp, College Station, TX). A two-tailed $P$ value less than 0.05 was considered statistically significant.

\section{Results}

As shown in Table 1, a total of 189 patients were included for analysis, among whom the median age was 53 (38, $62)$ years, and $52.9 \%(100 / 189)$ were female. Surprisingly, PPGLs were incidentally found in 59.3\% (112/189) of patients, who either had no symptoms or, in symptomatic cases, the symptoms were not considered to be related to the space-occupying effect of tumors or CA-related effects. Hypertension occurred in 97 (51.3\%) subjects, and a sustained pattern $(52 / 97,53.6 \%)$ was dominant over paroxysmal $(15 / 97,15.5 \%)$, mixed (19/97, 19.6\%), and unknown $(11 / 97,11.3 \%)$ patterns. With regard to symptoms documented in the medical records, abdominal discomfort (nausea or vomiting), chest pain, dyspnea and classic triad symptoms (headache, palpitation, and/ or profuse sweating) appeared in 9.5\% (18/189), 3.2\% (6/189), $14.8 \%(28 / 189)$ and $8.5 \%(16 / 189)$ of the included subjects, respectively. Troponin $(55 / 189,29.1 \%)$ and NT-proBNP $(51 / 189,27.0 \%)$ levels were tested in only approximately one-quarter of the study subjects. Seventy $(37.0 \%)$ patients were screened for tumors with CA secretion, as the plasma CA/MN/NMN test was unavailable until January 2018 in our center; however, the urine vanillylmandelic acid test was performed in 103 (54.5\%) cases, resulting in 135 (71.4\%) patients undergoing at least one of the aforementioned endocrine tests. The majority of patients underwent a routine urine examination (185/189, 97.9\%), ECG examination (182/189, $96.3 \%)$, blood count examination $(187 / 189,98.9 \%)$, and renal function examination $(188 / 189,99.5 \%)$. Of note, invasive behavior and the presence of hemorrhage/necrosis on pathology reports were described in $29.7 \%$ and
$20.0 \%$ of cases, respectively. Moreover, the proportion of patients who took antihypertensive medicine declined from $38.1 \%$ on admission to $12.2 \%$ at discharge $(P<0.05)$.

\section{Acute cardiac complications}

As depicted in Table 2, fourteen (7.4\%) patients suffered ACCs, including nine patients (4.8\%) with Takotsubolike cardiomyopathy, four $(2.1 \%)$ with heart failure with preserved ejection fraction (HFpEF) and one $(0.5 \%)$ with catecholamine-induced cardiomyopathy. Two patients displayed recurrent episodes of Takotsubo-like cardiomyopathy, of whom one (case 10, two times) had episodes 2 years apart and one (case 9, three times) had episodes 4 years apart. Predisposing factors were identified in only six (42.9\%) cases, consisting of physical activity or defecation in three cases, operation in one case, pregnancy in one case and respiratory tract infection in the remaining case. In addition, labile blood pressure was detected in five patients (35.7\%). Regarding the location of the tumors, diagnoses of PGLs were made in only two cases. In the eleven patients who were screened for plasma CA levels, the combination pattern $(8 / 11,72.7 \%)$ was dominant over the patterns of epinephrine predominance $(1 / 11,9.1 \%)$ and norepinephrine predominance $(2 / 11$, 18.2\%). All thirteen patients with biomarkers for cardiac injuries displayed elevated troponin $\mathrm{T}$ (median $437.6 \mathrm{pg} /$ $\mathrm{ml}$ ) and NT-proBNP levels (median $8946 \mathrm{pg} / \mathrm{ml}$ ). The mean value of left ventricular ejection fraction (LVEF) in the acute phase was 0.45 , with a range of $0.21-0.65$; notably, the LVEF reached the normal range by $6-30$ days in all nine patients diagnosed with Takotsubo-like cardiomyopathy. Due to familial PHEOs and other endocrine organ involvement, case 4 was diagnosed with multiple endocrine neoplasia type 2 without genetic testing. Case 14, a middle-aged male patient, underwent a repeat echocardiography examination 10 months after surgery, which showed no recovery of LVEF; hence, he was diagnosed with catecholamine-induced cardiomyopathy.

In comparison to the non-ACC group, the $\mathrm{ACC}$ group shared similar characteristics in sex (male, $71.4 \%$ vs $45.1 \%, P=0.058$ ) and age (median, 48 vs $54, P=0.320$ ). As expected, more patients with ACCs had hypertension $(78.6 \%$ vs $49.1 \%, P=0.034)$; however, the patterns of hypertension did not differ between the two groups $(P=0.266)$. Surprisingly, the proportions of subjects who displayed classic triad symptoms $(7.1 \%$ vs $8.6 \%$, $P=1.000)$ and chest pain $(14.3 \%$ vs $2.3 \%, P=0.065)$ were similar between the two groups and quite low in both; nevertheless, significantly more patients showed gastrointestinal symptoms $(50.0 \%$ vs $6.3 \%, P<0.001)$ and dyspnea $(100 \%$ vs $8.0 \%, P<0.001)$ in the ACC group. As expected, with regard to ECG changes, ST-segment changes $(28.6 \%$ vs $8.9 \%, P=0.043)$, $\mathrm{T}$ wave inversions 
Table 1 Clinical profiles of patients diagnosed with PPGLs and comparisons between the ACC group and the non-ACC group

\begin{tabular}{|c|c|c|c|c|}
\hline & All $(n=189)$ & Non-ACC $(n=175)$ & $\operatorname{ACC}(n=14)$ & $P$ value \\
\hline Male & $89(47.1)$ & $79(45.1)$ & $10(71.4)$ & 0.058 \\
\hline Age (years) & $53(38,62)$ & $54(38,62)$ & $48(38,52)$ & 0.320 \\
\hline History of hypertension & $97(51.3)$ & $86(49.1)$ & $11(78.6)$ & 0.034 \\
\hline Patterns of hypertension $(n=97)$ & & & & 0.266 \\
\hline Sustained & $52(53.6)$ & $49(57.0)$ & $3(27.3)$ & \\
\hline Paroxysmal & $15(15.5)$ & $13(15.1)$ & $2(18.2)$ & \\
\hline Mixed & $19(19.6)$ & $15(17.4)$ & $4(36.4)$ & \\
\hline Unknown & $11(11.3)$ & $9(10.5)$ & $2(18.2)$ & \\
\hline \multicolumn{5}{|l|}{ Symptoms } \\
\hline Nausea or vomiting & $18(9.5)$ & $11(6.3)$ & $7(50.0)$ & $<0.001$ \\
\hline Presence of chest pain & $6(3.2)$ & $4(2.3)$ & $2(14.3)$ & 0.065 \\
\hline Presence of dyspnea & $28(14.8)$ & $14(8.0)$ & $14(100)$ & $<0.001$ \\
\hline Presence of triad ${ }^{\mathrm{a}}$ & $16(8.5)$ & $15(8.6)$ & $1(7.1)$ & 1.000 \\
\hline \multicolumn{5}{|l|}{ ECG changes $(n=182)$} \\
\hline ST-segment changes & $19(10.4)$ & $15(8.9)$ & $4(28.6)$ & 0.043 \\
\hline Twave inversion & $29(15.3)$ & $22(13.1)$ & $7(50.0)$ & 0.002 \\
\hline Any abnormality ${ }^{c}$ & $91(50.0)$ & $77(45.8)$ & $14(100)$ & $<0.001$ \\
\hline \multicolumn{5}{|l|}{ Blood parameters } \\
\hline Hemoglobin $(g / L)(n=187)$ & $132.8 \pm 20.7$ & $132.5 \pm 20.2$ & $136.8 \pm 26.4$ & 0.452 \\
\hline Platelet count $\left(\times 10^{9} / \mathrm{L}\right)(\mathrm{n}=187)$ & $256.1 \pm 81.5$ & $251.9 \pm 76.6$ & $308.6 \pm 118.5$ & 0.100 \\
\hline White blood cell count $\left(\times 10^{9} / \mathrm{L}\right)(\mathrm{n}=187)$ & $6.6(5.5,8.6)$ & $6.4(5.4,8.1)$ & $15.6(12.1,18.9)$ & $<0.001$ \\
\hline $\operatorname{eGFR}\left(\mathrm{ml} / \mathrm{min} / 1.73 \mathrm{~m}^{2}\right)(\mathrm{n}=188)$ & $108.0(96.9,117.8)$ & $108.0(97.4,117.8)$ & $106.1(49.3,117.3)$ & 0.408 \\
\hline Proteinuria $(n=185)$ & $24(13.0)$ & $19(11.1)$ & $5(35.7)$ & 0.026 \\
\hline \multicolumn{5}{|l|}{ Cardiac biomarkers } \\
\hline Elevation of troponin $(n=55)$ & $19(34.5)$ & $6(14.3)$ & $13(100)$ & $<0.001$ \\
\hline Elevation of NT-proBNPb $(n=51)$ & $38(74.5)$ & $25(65.8)$ & $13(100)$ & 0.023 \\
\hline \multicolumn{5}{|l|}{ Patterns of secretion $(n=70)$} \\
\hline Unknown & $4(5.7)$ & $4(6.8)$ & $0(0)$ & \\
\hline Nonsecreting & $12(17.1)$ & $12(20.3)$ & $0(0)$ & 0.044 \\
\hline Epinephrine predominant & $5(7.1)$ & $4(6.8)$ & $1(9.1)$ & \\
\hline Norepinephrine predominant & $25(35.7)$ & $23(39.0)$ & $2(18.2)$ & \\
\hline A combination of both & $24(34.3)$ & $16(27.1)$ & $8(72.7)$ & \\
\hline \multicolumn{5}{|l|}{ Patterns of secretion $(n=70)^{d}$} \\
\hline Epinephrine secretion & $29(41.4)$ & $20(33.9)$ & $9(81.8)$ & 0.006 \\
\hline \multicolumn{5}{|l|}{ Tumor characteristics } \\
\hline Paragangliomas & $52(27.5)$ & $50(28.6)$ & $2(14.3)$ & 0.357 \\
\hline Bilateral adrenal tumors $(n=137)$ & $6(4.4)$ & $5(4.0)$ & $1(8.3)$ & 0.429 \\
\hline Right adrenal tumors $(n=137)$ & $70(51.1)$ & $64(51.2)$ & $6(50.0)$ & 0.937 \\
\hline Maximal tumor diameters $(\mathrm{cm})$ & $4.5(3.2,6)$ & $4.5(3,6)$ & $5.5(4.7,6.5)$ & 0.053 \\
\hline Invasive behavior at histology $(n=185)$ & $55(29.7)$ & $47(27.3)$ & $8(61.5)$ & 0.022 \\
\hline Hemorrhage/necrosis at histology $(n=185)$ & $37(20.0)$ & $30(17.4)$ & $7(53.9)$ & 0.005 \\
\hline \multicolumn{5}{|l|}{ Antihypertensive therapy } \\
\hline On admission & $72(38.1)$ & $65(37.1)$ & $7(50.0)$ & 0.341 \\
\hline At discharge & $23(12.2)^{\mathrm{e}}$ & 19 (10.9) & $4(28.6)$ & 0.073 \\
\hline
\end{tabular}

Continuous variables are expressed as mean \pm standard deviation or median ( 25 th, 75 th percentile); categorical variables are presented as number and percentages in parentheses. Missing data varied by variables

ACCs acute cardiac complications, cm centimetre, ECG electrocardiography, eGFR estimated glomerular filtration rate, NT-proBNP N-terminal pro-B type natriuretic peptide

a Defined as presentation of headache, palpitation, and/or profuse sweating

b Defined as NT-proBNP on admission equal to or greater than $125 \mathrm{pg} / \mathrm{ml}$

c Defined as any abnormal findings on ECG (e.g., arrhythmias, ST-segment changes, T wave changes, high voltage of left ventricle, etc.) 
Table 1 (continued)

${ }^{d}$ Categorized into two patterns: with and without epinephrine secretion ( $\geq 2 \times \mathrm{ULN}$, including metanephrine)

e $P<0.05$ compared with admission

(50.0\% vs $13.1 \%, P=0.002)$, and any abnormality $(100 \%$ vs $45.8 \%, P<0.001)$ were more prevalent in patients with ACCs than in those without ACCs. In terms of laboratory findings, proteinuria was more likely to be found in the ACC group (35.7\% vs $11.1 \%, P=0.026)$; likewise, the ACC group had a higher median level of white blood cells (median, 15.6 vs $6.4, P<0.001$ ). Regarding patterns of secretion, a combination pattern was dominant in patients with ACCs $(P=0.044)$; moreover, there was a higher prevalence of epinephrine-producing PPGLs $(81.8 \%$ vs $33.9 \%, P=0.006)$ among the ACC group. Overall, the proportions of paragangliomas, bilateral adrenal tumors, and right adrenal tumors were similar between the two groups; however, patients with ACCs exhibited a trend towards having larger maximal tumor diameters, but the difference did not reach statistical significance (median, 5.5 vs $4.5, P=0.053$ ). Interestingly, more patients in the ACC group showed invasive behavior (61.5\% vs $27.3 \%, P=0.022)$ and hemorrhage/necrosis (53.9\% vs $17.4 \%, P=0.005$ ) in pathology reports than patients in the non-ACC group. Finally, with respect to the proportion of patients who received antihypertensive therapy, two groups did neither differ on admission nor at discharge.

During the study period, 9432 patients diagnosed with ACS and/or AHF were identified from the electronic search, resulting in a prevalence of $0.15 \%$ for PPGLinduced ACCs in these patients.

\section{Strain analysis}

As shown in Table 2, 2D strain analysis was carried out in 9 (64.3\%) out of 14 patients with ACCs, and technical reasons accounted for failure to perform the analysis in the remaining 5 cases. Strikingly, 6 (66.7\%) patients displayed a pattern of relative apical sparing of LS; meanwhile, of the remaining 3 patients, one (case 1) showed a pattern of apical ballooning, one (case 10) displayed a pattern of segmental dysfunction, and the last patient (case 14) showed a pattern of global dysfunction. Of the 7 patients with Takotsubo-like cardiomyopathy who underwent strain analysis, one patient (case 1) (14.3\%) exhibited a typical apical ballooning pattern; however, 5 (71.4\%) (cases 2, 3, 4, 12, 13) patients showed a pattern of relative apical sparing of LS. Visual examples of the patterns of 'apical ballooning,' 'apical sparing,' 'global' and 'segmental' of LS are depicted in Fig. 1a-g. In addition, the mean value of GLS was $-11.0 \pm 5.8$, with a range of -5.5 to -21.2 .

\section{Subclinical myocardial injuries}

The prevalence of SMIs can be potentially underestimated owing to unthorough investigations or be overestimated because the decision to perform examinations was made at the discretion of the physicians in this study. Among 175 patients without ACCs, only 60 (34.3\%) patients underwent echocardiography examinations, 42 (24.0\%) received troponin tests and 38 (21.7\%) underwent NT-proBNP tests; furthermore, 77 (44.0\%) patients received at least one of the aforementioned three examinations, among whom 21 (27.3\%) patients experienced SMIs, including elevated NT-proBNP levels in 15, elevated troponin in 4 and abnormal findings on echocardiography examinations in 10 patients (shown in Table 3). Additionally, among the above 77 patients, 40 exhibited any abnormality on ECG, including 7 (17.5\%) who fulfilled the criteria for SMIs.

\section{Discussion}

In this retrospective study with a large sample size (189 cases), we demonstrated a relatively high prevalence (7.4\%) of ACCs owing to CA excess in patients with PPGLs. Moreover, 9 out of 14 patients with ACCs displayed Takotsubo-like cardiomyopathy, and 2D strain analysis further revealed that the predominant impairment pattern was the apical sparing pattern (5/7), which was dominant over the typical apical ballooning pattern $(1 / 7)$ seen in TTS. In fact, we believed that some, if not all, patients diagnosed with HFpEF had gone through the clinical course of Takotsubo-like cardiomyopathy, since strain analysis showed impaired strain in case 6. Of note, a fairly high incidence (27.3\%) of SMIs was observed in patients who underwent cardiac biomarker and/or echocardiography examinations, suggesting the universality of CA-related cardiac damage.

In this study, the majority (59.3\%) of PPGLs were found incidentally based on abdominal ultrasonogram or CT/MRI scans rather than PPGL-related symptoms. The main discovery method is consistent with that in recent cohort studies, implying changes in PPGL recognition due to the widespread use of cross-sectional imaging; hence, the relatively low prevalence of hypertension and symptoms might be explained by the fact that most PPGLs have been incidentally found in recent years $[12,13]$. Nausea or vomiting occurred in half of the patients with ACCs, which should be partly, if not totally, ascribed to excessive CA secretion [13]. These data were 
Table 2 Characteristics of patients presenting with ACCs

\begin{tabular}{|c|c|c|c|c|c|c|c|c|c|c|}
\hline Case & Acute LVEF (\%) & Strain analysis & \multicolumn{2}{|c|}{$\begin{array}{l}\text { Impairment patterns } \\
\text { of LS }\end{array}$} & Acute global LS & \multicolumn{2}{|c|}{$\begin{array}{l}\text { Coronary artery } \\
\text { evaluation }\end{array}$} & \multicolumn{2}{|c|}{$\begin{array}{l}\text { Recovery time on } \\
\text { imaging }\end{array}$} & Clinical diagnosis \\
\hline 1 & 0.38 & Yes & \multicolumn{2}{|l|}{ Apical ballooning } & -5.5 & \multicolumn{2}{|l|}{ CTA: $(-)$} & \multicolumn{2}{|l|}{6 days } & Takotsubo syndrome \\
\hline 2 & 0.39 & Yes & \multicolumn{2}{|l|}{ Apical sparing } & -10.7 & \multicolumn{2}{|l|}{ CAG: $(-)$} & \multicolumn{2}{|l|}{7 days } & Takotsubo syndrome \\
\hline 3 & 0.45 & Yes & \multicolumn{2}{|l|}{ Apical sparing } & -4.8 & \multicolumn{2}{|c|}{ Without risk factors } & \multicolumn{2}{|l|}{30 days } & Takotsubo syndrome \\
\hline 4 & 0.21 & Yes & \multicolumn{2}{|l|}{ Apical sparing } & -6.1 & \multicolumn{2}{|c|}{ Without risk factors } & \multicolumn{2}{|l|}{14 days } & Takotsubo syndrome \\
\hline 5 & 0.62 & No & \multicolumn{2}{|l|}{-} & - & \multicolumn{2}{|c|}{ CAG: $(-)$} & \multicolumn{2}{|l|}{-} & HFpEF \\
\hline 6 & 0.64 & Yes & \multicolumn{2}{|l|}{ Apical sparing } & -16.8 & \multicolumn{2}{|l|}{ CTA: (-) } & \multicolumn{2}{|l|}{-} & HFpEF \\
\hline 7 & 0.43 & No & \multicolumn{2}{|l|}{-} & - & \multicolumn{2}{|c|}{$\begin{array}{l}\text { CTA: } p-R C A \text { 50\% } \\
\text { stenosis }\end{array}$} & \multicolumn{2}{|l|}{12 days } & Takotsubo syndrome \\
\hline 8 & 0.61 & No & - & & - & - & & - & & HFpEF, ischemic stroke \\
\hline 9 & 0.36 & No & - & & - & Without risk & factors & 11 days & & $\begin{array}{l}\text { Recurrent Takotsubo } \\
\text { syndrome (3 times) }\end{array}$ \\
\hline 10 & 0.38 & Yes & Segmental & & -21.2 & CTA: (-) & & 11 days & & $\begin{array}{l}\text { Recurrent Takotsubo } \\
\text { syndrome ( } 2 \text { times) }\end{array}$ \\
\hline 11 & 0.65 & No & - & & - & Without risk & factors & - & & HFpEF \\
\hline 12 & 0.59 & Yes & Apical sparing & & -9.6 & Without risk & factors & 7 days & & Takotsubo syndrome \\
\hline 13 & 0.35 & Yes & Apical sparing & & -13.6 & CAG: (-) & & 15 days & & Takotsubo syndrome \\
\hline 14 & 0.28 & Yes & Global & & - & CAG: (-) & & $\begin{array}{l}\text { Without recove } \\
10 \text { months }\end{array}$ & ery in & $\begin{array}{l}\text { Catecholamine- } \\
\text { induced cardiomyo- } \\
\text { pathy }\end{array}$ \\
\hline Case & $\begin{array}{l}\text { Sex/age } \\
\text { (years)* }^{*}\end{array}$ & $\begin{array}{l}\text { Initial } \\
\text { symptoms }\end{array}$ & Triggers & $\begin{array}{l}\text { Labile } \\
\text { blood } \\
\text { pressure }\end{array}$ & $\begin{array}{l}\text { Location of } \\
\text { tumors }\end{array}$ & $\begin{array}{l}\text { Plasma } \\
\text { catechol } \\
(\times \text { ULN) } \\
\end{array}$ & amine & $\begin{array}{l}\text { Troponin (pg/ } \\
\mathrm{ml} \text { ) }\end{array}$ & $\begin{array}{l}\text { NT-proBNF } \\
(\mathrm{pg} / \mathrm{ml})\end{array}$ & NP \\
\hline & & & & & & $\mathrm{E} / \mathrm{MN}$ & NE/NMN & & & \\
\hline 1 & $50 \mathrm{~s} / \mathrm{male}$ & $\begin{array}{l}\text { Nausea, } \\
\text { vomiting, } \\
\text { dyspnea, } \\
\text { palpitation }\end{array}$ & $\begin{array}{l}\text { Physical } \\
\text { activity }\end{array}$ & No & $\begin{array}{l}\text { Left adrenal } \\
\text { PHEO }\end{array}$ & 5.9 & 2.5 & 1159 & $>35,000$ & $\begin{array}{l}\text { Sinus tachy- } \\
\text { cardia, ST } \\
\text { depression } \\
\text { and T wave } \\
\text { inversion in } \\
V_{4-6}\end{array}$ \\
\hline 2 & $30 \mathrm{~s} / \mathrm{male}$ & $\begin{array}{l}\text { Nausea, } \\
\text { vomiting, } \\
\text { dyspnea, } \\
\text { palpitation, } \\
\text { headache }\end{array}$ & $\begin{array}{l}\text { Physical } \\
\text { activity }\end{array}$ & No & $\begin{array}{l}\text { Bilateral adre- } \\
\text { nal PHEO }\end{array}$ & - 15.8 & 4.2 & 1220 & 5976 & $\begin{array}{l}\text { ST depression } \\
\text { and T inver- } \\
\text { sion in } V_{1-6 \prime} \\
\text { prolonged } \\
\text { QTc interval }\end{array}$ \\
\hline 3 & 10 s/female & Dyspnea & Infection & No & $\begin{array}{l}\text { Right adrenal } \\
\text { PHEO }\end{array}$ & Normal & $>12.1$ & 19.3 & 2985 & $\begin{array}{l}\text { Sinus tachy- } \\
\text { cardia }\end{array}$ \\
\hline 4 & $40 \mathrm{~s} / \mathrm{male}$ & $\begin{array}{l}\text { Dyspnea, } \\
\text { palpitation, } \\
\text { sweating }\end{array}$ & No & Yes & $\begin{array}{l}\text { Right adrenal } \\
\text { PHEO }\end{array}$ & 4.0 & Normal & 2773 & 25,492 & $\begin{array}{l}\text { Sinus } \\
\text { tachycardia, } \\
\text { nonspecific } \\
\text { Twave } \\
\text { changes }\end{array}$ \\
\hline 5 & 40 s/female & dyspnea & No & No & $\begin{array}{l}\text { Left adrenal } \\
\text { PHEO }\end{array}$ & 11.2 & 11.9 & 77.3 & 4740 & $\begin{array}{l}\text { T wave } \\
\text { inversion } \\
\text { in inferior } \\
\text { leads }\end{array}$ \\
\hline 6 & $60 \mathrm{~s} / \mathrm{male}$ & $\begin{array}{l}\text { Dyspnea, } \\
\text { palpitation, } \\
\text { sweating }\end{array}$ & No & No & $\begin{array}{l}\text { Left adrenal } \\
\text { PHEO }\end{array}$ & 2.6 & 57.5 & 84.3 & 7976 & $\begin{array}{l}\text { Diminished } R \\
\text { wave in } V_{2-3}\end{array}$ \\
\hline 7 & $50 \mathrm{~s} / \mathrm{male}$ & $\begin{array}{l}\text { Dyspnea, } \\
\text { chest pain }\end{array}$ & Operation & No & $\begin{array}{l}\text { Right adrenal } \\
\text { PHEO }\end{array}$ & al & - & 130.2 & 2250 & $\begin{array}{l}\text { Premature } \\
\text { atrial com- } \\
\text { plex }\end{array}$ \\
\hline 8 & 60 s/female & $\begin{array}{l}\text { Nausea, } \\
\text { vomiting, } \\
\text { dyspnea, } \\
\text { sweating }\end{array}$ & Defecation & Yes & $\begin{array}{l}\text { Right adrenal } \\
\text { PHEO }\end{array}$ & al & - & 437.6 & 33,914 & $\begin{array}{l}\text { T wave } \\
\text { inversion } \\
\text { in inferior } \\
\text { leads and } \\
\mathrm{V}_{2-6}\end{array}$ \\
\hline
\end{tabular}


Table 2 (continued)

\begin{tabular}{|c|c|c|c|c|c|c|c|c|c|c|}
\hline \multirow[t]{2}{*}{ Case } & \multirow[t]{2}{*}{$\begin{array}{l}\text { Sex/age } \\
\text { (years) }\end{array}$} & \multirow[t]{2}{*}{$\begin{array}{l}\text { Initial } \\
\text { symptoms }\end{array}$} & \multirow[t]{2}{*}{ Triggers } & \multirow[t]{2}{*}{$\begin{array}{l}\text { Labile } \\
\text { blood } \\
\text { pressure }\end{array}$} & \multirow[t]{2}{*}{$\begin{array}{l}\text { Location of } \\
\text { tumors }\end{array}$} & \multicolumn{2}{|c|}{$\begin{array}{l}\text { Plasma } \\
\text { catecholamine } \\
(\times \cup L N) \\
\end{array}$} & \multirow[t]{2}{*}{$\begin{array}{l}\text { Troponin (pg/ } \\
\text { ml) }\end{array}$} & \multirow[t]{2}{*}{$\begin{array}{l}\text { NT-proBNP } \\
(\mathrm{pg} / \mathrm{ml})\end{array}$} & \multirow[t]{2}{*}{ ECG } \\
\hline & & & & & & E/MN & NE/NMN & & & \\
\hline 9 & $20 \mathrm{~s} / \mathrm{male}$ & $\begin{array}{l}\text { Nausea, } \\
\text { dyspnea, } \\
\text { palpitation, } \\
\text { sweating }\end{array}$ & No & Yes & $\begin{array}{l}\text { Left adrenal } \\
\text { PHEO }\end{array}$ & 8.4 & 11.4 & 663.6 & 26,508 & $\begin{array}{l}\text { Sinus tachy- } \\
\text { cardia, sec- } \\
\text { ond degree } \\
\text { AVB }\end{array}$ \\
\hline 10 & 70 s/male & $\begin{array}{l}\text { Nausea, } \\
\text { vomiting, } \\
\text { dyspnea }\end{array}$ & No & No & $\begin{array}{l}\text { Right adrenal } \\
\text { PHEO }\end{array}$ & 9.4 & 2.9 & 2178 & $>35,000$ & $\begin{array}{l}\text { Sinus tachy- } \\
\text { cardia, low } \\
\text { voltage in } \\
\text { limb leads, } \\
\text { ST depres- } \\
\text { sion in } V_{3-6}\end{array}$ \\
\hline 11 & 30 s/female & $\begin{array}{l}\text { Dyspnea, } \\
\text { palpitation, } \\
\text { sweating }\end{array}$ & Pregnancy & Yes & $\begin{array}{l}\text { Retroperito- } \\
\text { neal PGL }\end{array}$ & - & - & - & - & $\begin{array}{l}\text { Twave } \\
\text { inversion } \\
\text { in inferior } \\
\text { leads and } \\
V_{3-6}\end{array}$ \\
\hline 12 & 40 s/male & $\begin{array}{l}\text { Nausea, } \\
\text { vomiting, } \\
\text { dyspnea, } \\
\text { headache }\end{array}$ & No & Yes & $\begin{array}{l}\text { Right adrenal } \\
\text { PHEO }\end{array}$ & 25.1 & 16.0 & 121.9 & 8946 & $\begin{array}{l}\text { T wave inver- } \\
\text { sion in I, aVL, } \\
\text { and V6 }\end{array}$ \\
\hline 13 & 40 s/male & $\begin{array}{l}\text { Nausea, } \\
\text { vomiting, } \\
\text { dyspnea, } \\
\text { chest pain, } \\
\text { headache }\end{array}$ & No & No & $\begin{array}{l}\text { Left adrenal } \\
\text { PHEO }\end{array}$ & 10.4 & 7.6 & 954.2 & 12,913 & $\begin{array}{l}\text { ST depression } \\
\text { in inferior } \\
\text { leads and } \\
V_{4-6} \text { ST } \\
\text { elevation in } \\
\text { aVR }\end{array}$ \\
\hline 14 & $50 \mathrm{~s} / \mathrm{male}$ & Dyspnea & No & No & Pelvic PGL & Normal & $>12.1$ & 72.1 & 1208 & $\begin{array}{l}\text { Sinus tachy- } \\
\text { cardia, LBBB }\end{array}$ \\
\hline
\end{tabular}

$A V B$ atrioventricular block, CAG coronary artery angiography, CTA coronary computed tomography angiography, $E$ epinephrine, $H F p E F$ heart failure with preserved ejection fraction, $L B B B$ left bundle branch block, $L V E F$ left ventricular ejection fraction, $L S$ longitudinal strain, $L V$ left ventricle, $M N$ metanephrine, $N E$ norepinephrine, $N M N$ normetanephrine, $P G L$ paraganglioma, $P H E O$ pheochromocytoma, $p-R C A$ proximal right coronary artery, ULN upper limit of normal. Other abbreviations as shown in Table 1

${ }^{*}$ Ages expressed in decades to ensure patient anonymity in Tables 2 and 3

surprising to us given less than ten percent of patients showed classical triad symptoms; this rate was lower than the prevalence (17\%) reported by a recent study [13] and might be underestimated owing to the retrospective nature of the study. However, a low prevalence (4\%) of the classical triad in patients with PPGL-induced reversible cardiomyopathy was also reported by a recent review, which could help remind clinicians to consider PPGLs in the context of reversible cardiomyopathy with unclear aetiology and not to rely on the classical triad as a diagnostic threshold [3].

Proteinuria was more prevalent in patients with ACCs than in non-ACC controls, implying more severe kidney injury caused by CAs or cytokines released from PPGLs [14]. Notably, epinephrine secretion was present in most patients $(81.8 \%)$ with ACCs, which was consistent with previous studies [4], indicating that the episodical release of epinephrine caused sudden cardiac decompensation as opposed to the persistent storage and release of norepinephrine $[15,16]$. A trend towards a larger tumor diameter in the ACC group than in the non-ACC group $(P=0.053)$ was observed, but inconsistent correlations between tumor size and ACCs have been reported in prior studies [5-7]. The presence of hemorrhage/necrosis on histology was more often seen in subjects with ACCs than in those without, suggesting a possible role as triggers played by hemorrhage/necrosis [2, 17]. In agreement with the recognition that all PPGLs have a metastatic risk, we reported a fairly high rate of invasive behavior on pathology reports (29.7\%). Additionally, invasive behavior seemed to be associated with ACCs; however, the result should be considered exploratory owing to the lack of standardized interpretation of pathology results and well-accepted histological features indicating metastasis for PPGLs [18].

The prevalence $(4.8 \%)$ of Takotsubo-like cardiomyopathy in our cohort was comparable with the prevalence of $1.4 \sim 5.6 \%$ reported in previous studies [4-8]. The apical sparing pattern (5/7), indicating the impairment of segments in the mid-ventricular and basal regions, was 


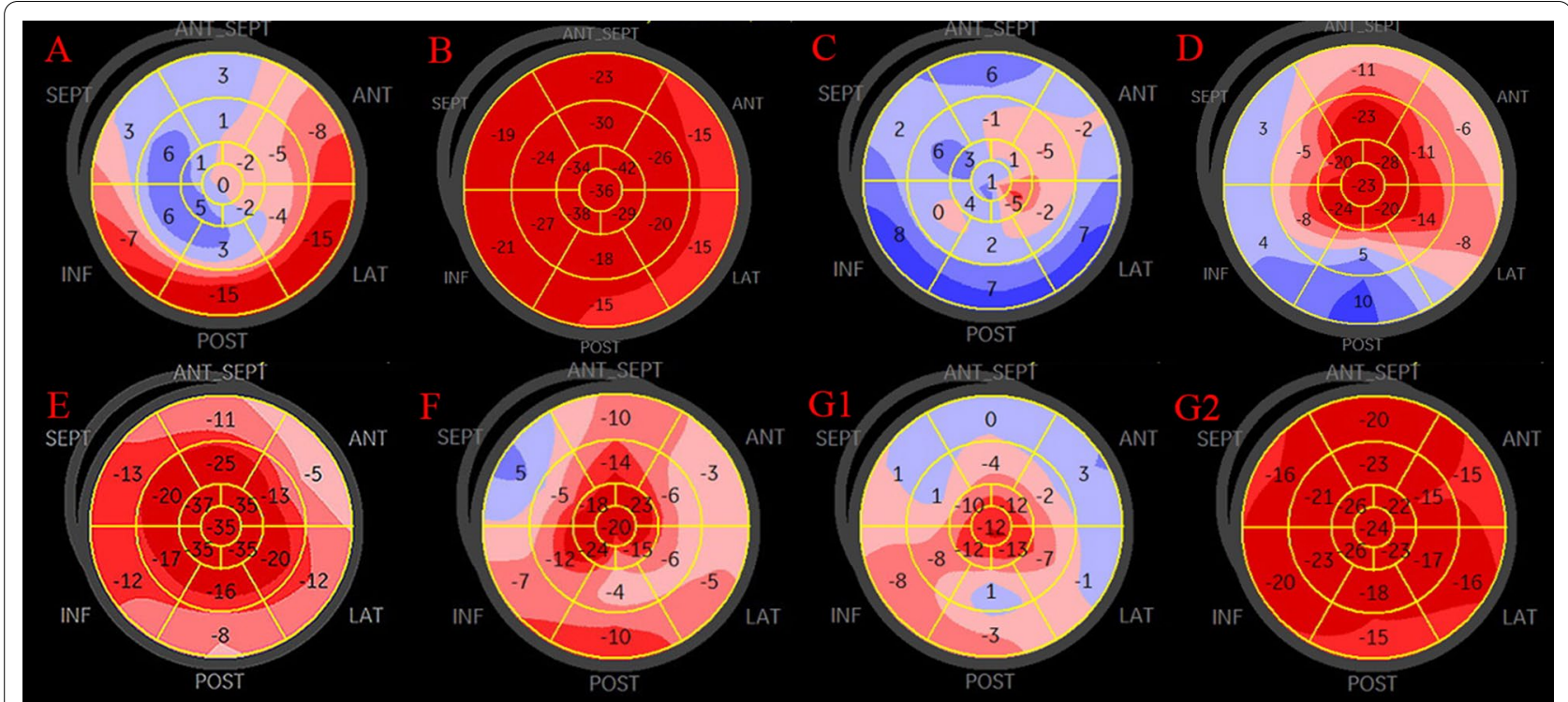

Fig. 1 Representative impairment patterns of longitudinal strain for each subgroup. a The pattern of apical ballooning in case 1. b The pattern of segmental dysfunction in case 10. cThe pattern of global dysfunction in case 14. d-f The patterns of apical sparing in cases 2, 6, and 12. g1, 2 The apical sparing pattern during the acute phase and a nearly full recovery 14 days later in case 4

the dominant impairment pattern of LS, whereas prior reviews revealed a predominance $(48 \%)$ of the classical apical ballooning pattern on routine echocardiography examinations $[3,4]$. The different impaired patterns between PPGL-induced TTS and classic TTS may hint that distinct pathogenetic mechanisms exist $[19,20]$. Recurrent TTS associated with PPGLs was recently reported and systematically reviewed by our team [21]; of note, two patients in this cohort who experienced recurrent episodes of TTS were diagnosed with myocarditis 2-4 years before PPGLs were identified, highlighting the value of screening for PPGLs among these patients. Although, as revealed in this study, the prevalence of PPGLs was extremely low $(0.15 \%)$ in the general population presenting with ACS and/or AHF, clinicians should consider such tumors when the patients exhibit the following features: no risk factors for heart failure, labile blood pressure, presence of a retroperitoneal tumor, and Takotsubo-like cardiomyopathy (especially displaying an apical sparing pattern of LS).

Unexpectedly, a quite high prevalence (27.3\%) of SMIs in patients with PPGLs was observed in our study, implying that cardiac injuries without clinical manifestations are common in the presence of excessive CA release. Abnormalities on ECG examinations, including sinus tachycardia, atrial fibrillation, premature complex, and nonspecific ST-T changes, were not deemed SMIs because they were nonspecific for PPGL-related cardiac damage; hence, the occurrence rate of SMIs might be underestimated.

\section{Strengthens and limitations of this study}

This study is the first study to investigate PPGL-induced ACCs and SMIs in an East-Asian population using a large sample size. This is the first study to characterize echocardiography abnormalities on strain analysis and demonstrate that the primary impairment pattern is the apical sparing pattern. In addition, the high prevalence, which is possibly underestimated, of SMIs observed in this study has not been reported in previous cohort studies. However, limitations exist, including the following: first, we were not able to perform comprehensive assessments of the cardiac injuries associated with exceedingly high levels of CAs because of the retrospective nature of the study; second, due to lack of genetic screening, the diagnoses made in this cohort failed to meet the requirements recommended by current guidelines [10]; third, the low number of events made it impossible to conduct regression analyses to reveal the independent factors associated with ACCs; and finally, these results should be generalized with caution owing to center-specific referral bias.

\section{Conclusion}

Collectively, this retrospective study revealed that one in every fourteen PPGL patients presented with ACCs. The main impairment pattern in patients with TTS on strain analysis was the apical sparing pattern, which is a distinct result from previous studies. Moreover, nearly one-third of patients without symptoms had SMIs. Clinical clues suggestive of PPGLs should not solely include adrenergic 


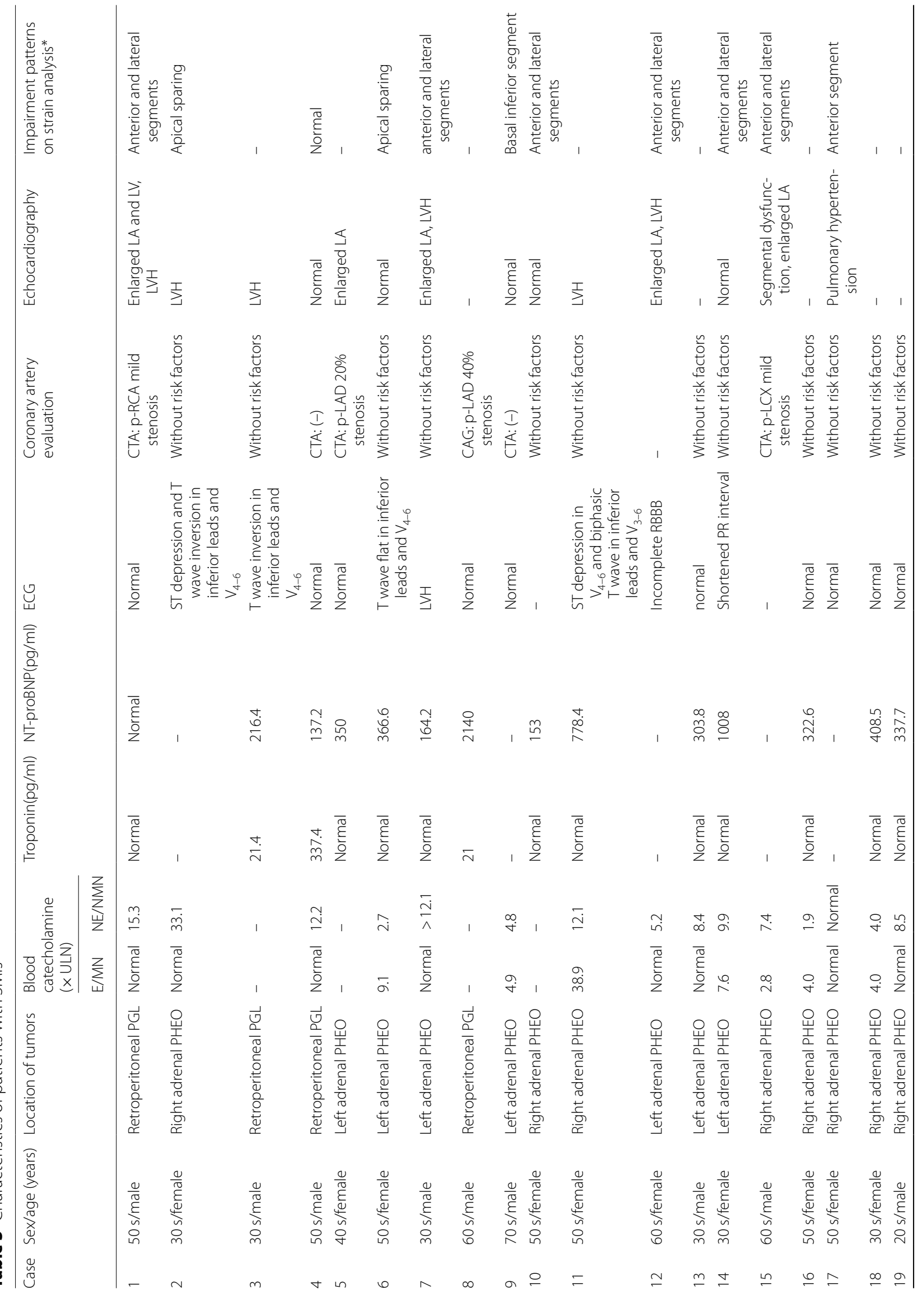




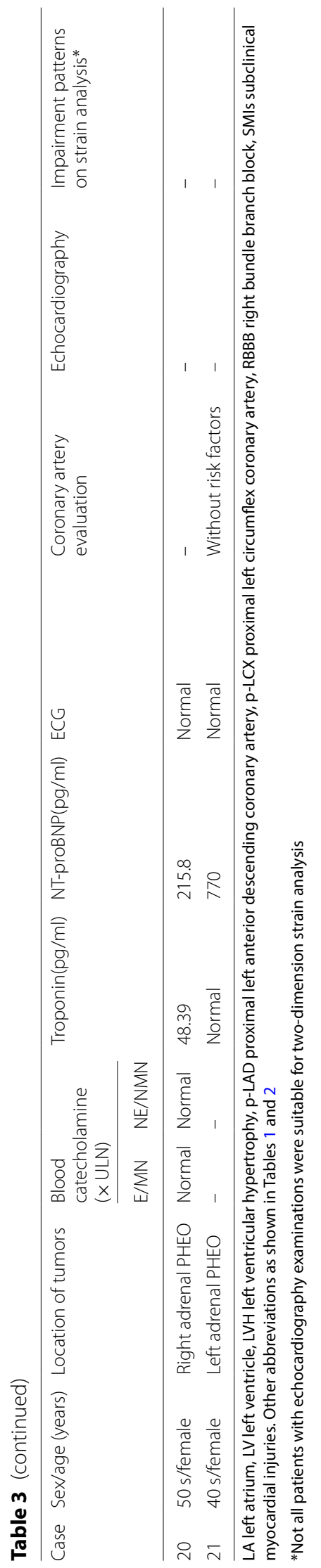


symptoms, particularly the classic triad, due to their extremely low prevalence. Clinicians should consider PPGLs in patients with acute reversible cardiomyopathy, especially in those displaying an apical sparing pattern of LS.

\section{Abbreviations}

2D: Two-dimensional; ACCs: Acute cardiac complications; ACS: Acute coronary syndrome; AHF: Acute heart failure; CAG: Coronary artery angiography; CAs: Catecholamines; CT: Computed tomography; CTA: Coronary computed tomography angiography; ECG: Electrocardiography; ESC: European Society of Cardiology; eGFR: Estimated glomerular filtration rate; GLS: Global longitudinal strain; HFpEF: Heart failure with preserved ejection fraction; IRB: Institutional Review Boards; LVEF: Left ventricular ejection fraction; LS: Longitudinal strain; MN: Metanephrine; MRI: Magnetic resonance imaging; NMN: Normetanephrine; NT-proBNP: N-terminal pro-B type natriuretic peptide; PGLs: Paragangliomas; PHEOs: Pheochromocytomas; PPGLs: Pheochromocytomas and paragangliomas; SD: Standard deviation; SMIs: Subclinical myocardial injuries; TTS: Takotsubo syndrome; ULN: Upper limit of normal.

\section{Acknowledgements}

None.

\section{Authors' contributions}

Y-LD designed this study. JZ, J-TH and HX made substantial contributions to acquisition of the data. Y-LD, JZ and HX were involved in data analysis. 2D strain analysis was performed by Y-XM. Y-LD, JZ and HX wrote the manuscript. All authors read and approved the final manuscript.

\section{Funding}

No funding was received for this study.

\section{Availability of data and materials}

The datasets used and/or analyzed during the current study are not publicly available due to the protection of individual privacy, but are available from the corresponding author on reasonable request.

\section{Declarations}

\section{Ethics approval and consent to participate}

The study was approved by the Institutional Review Board (IRB) of Soochow University. All patient records were anonymized before analysis and the requirement for informed consent was waived by the IRB of Soochow University due to the retrospective nature of the study.

\section{Consent for publication}

Not applicable.

\section{Competing interests}

The author declare that they have no competing interests.

\section{Author details}

1 Department of Cardiology, The First Affiliated Hospital of Soochow University, 188 Shizi Road, Suzhou City 215006, People's Republic of China. ${ }^{2}$ Department of Echocardiography, The First Affiliated Hospital of Soochow University, Suzhou City, Jiangsu Province, People's Republic of China.

Received: 11 December 2020 Accepted: 14 April 2021

Published online: 21 April 2021

\section{References}

1. Shams Y, Falhammar H. Cardiovascular manifestations and complications of pheochromocytomas and paragangliomas. J Clin Med. 2020;9(8):2435.

2. Lenders JWM, Eisenhofer G, Mannelli M, Pacak K. Phaeochromocytoma. The Lancet. 2005;366(9486):665-75.
3. Zhang R, Gupta D, Albert SG. Pheochromocytoma as a reversible cause of cardiomyopathy: analysis and review of the literature. Int J Cardiol. 2017:249:319-23.

4. Gagnon N, Mansour S, Bitton Y, Bourdeau I. Takotsubo-like cardiomyopathy in a large cohort of patients with pheochromocytoma and paraganglioma. Endocr Pract. 2017;23(10):1178-92.

5. Riester A, Weismann D, Quinkler M, Lichtenauer UD, Sommerey S, Halbritter R, Penning R, Spitzweg C, Schopohl J, Beuschlein F, et al. Lifethreatening events in patients with pheochromocytoma. Eur J Endocrinol. 2015;173(6):757-64

6. Giavarini A, Chedid A, Bobrie G, Plouin PF, Hagège A, Amar L. Acute catecholamine cardiomyopathy in patients with phaeochromocytoma or functional paraganglioma. Heart (British Cardiac Society). 2013;99(19):1438-44.

7. Zelinka T, Petrák O, Turková H, Holaj R, Strauch B, Kršek M, Vránková AB, Musil Z, Dušková J, Kubinyi J, et al. High incidence of cardiovascular complications in pheochromocytoma. Hormone Metab Res. 2012;44(5):379-84.

8. Park JH, Kim KS, Sul JY, Shin SK, Kim JH, Lee JH, Choi SW, Jeong JO, Seong IW. Prevalence and patterns of left ventricular dysfunction in patients with pheochromocytoma. J Cardiovasc Ultrasound. 2011;19(2):76-82.

9. Ghadri JR, Wittstein IS, Prasad A, Sharkey S, Dote K, Akashi YJ, Cammann VL, Crea F, Galiuto L, Desmet W, et al. International expert consensus document on Takotsubo syndrome (part I): clinical characteristics, diagnostic criteria, and pathophysiology. Eur Heart J. 2018;39(22):2032-46.

10. Lenders JWM, Kerstens MN, Amar L, Prejbisz A, Robledo M, Taieb D, Pacak K, Crona J, Zelinka T, Mannelli M, et al. Genetics, diagnosis, management and future directions of research of phaeochromocytoma and paraganglioma: a position statement and consensus of the Working Group on Endocrine Hypertension of the European Society of Hypertension. J Hypertens. 2020:38(8):1443-56.

11. Levey AS, Stevens LA, Schmid CH, Zhang YL, Castro AF 3rd, Feldman HI, Kusek JW, Eggers P, Van Lente F, Greene T, et al. A new equation to estimate glomerular filtration rate. Ann Intern Med. 2009;150(9):604-12.

12. Gruber LM, Hartman RP, Thompson GB, McKenzie TJ, Lyden ML, Dy BM, Young WF, Bancos I. Pheochromocytoma characteristics and behavior differ depending on method of discovery. J Clin Endocrinol Metab. 2019;104(5):1386-93.

13. Falhammar $\mathrm{H}$, Kjellman $\mathrm{M}$, Calissendorff J. Initial clinical presentation and spectrum of pheochromocytoma: a study of 94 cases from a single center. Endocr Connect. 2018;7(1):186-92.

14. Porzig A, Matthay KK, Dubois S, Pampaloni M, Damon L, Hawkins R, Goldsby $R$, Hollinger F, Fitzgerald P. Proteinuria in metastatic pheochromocytoma is associated with an increased risk of Acute Respiratory Distress Syndrome, spontaneously or after therapy with 1311-meta-iodobenzylguanidine (1311-MIBG). Hormone Metab Res. 2012;44(7):539-42.

15. Gupta G, Pacak K. Precision medicine: an update on genotype/biochemical phenotype relationships in pheochromocytoma/paraganglioma patients. Endocr Pract. 2017;23(6):690-704.

16. Eisenhofer G, Huynh TT, Elkahloun A, Morris JC, Bratslavsky G, Linehan WM, Zhuang Z, Balgley BM, Lee CS, Mannelli M, et al. Differential expression of the regulated catecholamine secretory pathway in different hereditary forms of pheochromocytoma. Am J Physiol Endocrinol Metab. 2008;295(5):E1223-1233.

17. Prejbisz A, Lenders JW, Eisenhofer G, Januszewicz A. Cardiovascular manifestations of phaeochromocytoma. J Hypertens. 2011;29(11):2049-60.

18. Turchini J, Cheung VKY, Tischler AS, De Krijger RR, Gill AJ. Pathology and genetics of phaeochromocytoma and paraganglioma. Histopathology. 2018:72(1):97-105.

19. Yh S. Clinical features and outcome of pheochromocytoma-induced takotsubo syndrome: analysis of 80 published cases. Am J Cardiol. 2016;117(11):1836-44.

20. Awad HH, McNeal AR, Goyal H. Reverse Takotsubo cardiomyopathy: a comprehensive review. Ann Transl Med. 2018;6(23):460.

21. Dai YL, Zhou J, Lin J, Hu JT, Zhao X. Recurrent Takotsubo syndrome associated with pheochromocytoma: a case report. Zhonghua Nei Ke Za Zhi. 2020;59(6):464-7.

\section{Publisher's Note}

Springer Nature remains neutral with regard to jurisdictional claims in published maps and institutional affiliations. 